\title{
Paraedwardsia malakhovi, a new burrowing sea anemone (Actiniaria: Edwardsiidae) from Kamchatka and Kuril Islands
}

\author{
N.P. Sanamyan, K.E. Sanamyan \\ Kamchatka Branch of Pacific Geographical Institute, Far-Eastern Branch of the Russian Academy \\ of Sciences, Partizanskaya 6, Petropavlovsk-Kamchatsky, 683000, Russia. \\ E-mail: actiniaria@sanamyan.com
}

ABSTRACT: Burrowing sea anemone Paraedwardsia malakhovi sp.n. is described from shallow-waters of East Kamchatka and middle group of Kuril Islands. This is a first record of a member of the genus Paraedwardsia from Far East Seas of Russia. A new replacement name Edwardsiellinae nom.n. is established for subfamily Milneedwardsiinae Carlgren, 1892.

How to cite this article: Sanamyan N.P., Sanamyan K.E. 2021. Paraedwardsia malakhovi, a new burrowing sea anemone (Actiniaria: Edwardsiidae) from Kamchatka and Kuril Islands // Invert.Zool. Vol.18. No.3. P.332-344. doi: 10.15298/invertzool.18.3.07

KEY WORDS: sea anemone, Actiniaria, NW Pacific, Edwardsiidae, Paraedwardsia, Edwardsiella, Edwardsiellinae nom.n.

\section{Paraedwardsia malakhovi, новая роющая актиния (Actiniaria: Edwardsiidae) из вод Камчатки и Курильских островов}

\author{
Н.П. Санамян, К.Э. Санамян
}

Камчатский филиал Тихоокеанского института географии ДВО РАН, ул. Партизанская, 6 , Петропавловск-Камчатский, 683000, Россия. E-mail: actiniaria@sanamyan.com

РЕЗЮМЕ: Роющая актиния Paraedwardsia malakhovi sp.n. описана с небольших глубин у побережья Восточной Камчатки и средних Курильских островов. Это первая находка представителя рода Paraedwardsia в дальневосточных морях. Новое замещающее название Edwardsiellinae nom.n. установлено для подсемейства Milneedwardsiinae Carlgren, 1892.

Как цитировать эту статью: Sanamyan N.P., Sanamyan K.E. 2021. Paraedwardsia malakhovi, a new burrowing sea anemone (Actiniaria: Edwardsiidae) from Kamchatka and Kuril Islands // Invert. Zool. Vol.18. No.3. P.332-344. doi: 10.15298/invertzool.18.3.07

КЛЮЧЕВЫЕ СЛОВА: морские анемоны, Actiniaria, Северо-Западная Пацифика, Edwardsiidae, Paraedwardsia, Edwardsiella, Edwardsiellinae nom.n.

The paper is devoted to 70th anniversary of Prof. V.V. Malakhov.

Статья посвящена 70-летию со дня рождения проф., акад. В.В. Малахова. 


\section{Introduction}

Family Edwardsiidae comprises numerous and widespread species of burrowing marine anemones readily distinguished by the presence of eight macromesenteries with strong retractors arranged "as in Edwardsia" (see Figs 3A, 4). Surprisingly, almost nothing is known about species of this family inhabiting eastern coasts of Russia and adjacent waters: western half of the Bering Sea, Pacific waters around Commander Islands and Kamchatka, Sea of Okhotsk and Kuril Islands and northern part of the Sea of Japan, a huge region (more than $3500 \mathrm{~km}$ in meridional direction) usually referred as Far East Seas of Russia. Although edwardsiid sea anemones periodically are caught by trawls during various hydrobiological cruises in this region (personal data), and they are numerous in certain localities (Kostina, 2008), and numerous species were described recently from Japan by Japanese authors (Izumi, Fujita, 2018, 2019; Izumi et al., 2018a, b), till now only one species was known in all Far East Seas of Russia which identification to the species level is confirmed: Edwardsia sojabio Sanamyan et Sanamyan, 2012. It was described from abyssal depths of the Sea of Japan (see Sanamyan, Sanamyan, 2012).

In 2010 Nadya Sanamyan discovered and photographed underwater a species definitely belonging to the family Edwardsiidae in vicinity of Starichkov Island located in the Avacha Gulf (east coast of Kamchatka). Unfortunately, at that time only one specimen was found and collected. During many subsequent years we tried to find this species again, but most our efforts were unsuccessful: dark (brownish-greenish-gray) specimens are difficult to see on sandy bottom and, moreover, on any attempt to collect, at the slightest disturbance, they instantly hide in the sand and there is no chance to catch them between the stones. This also apply to bright specimens of the same species which were found in 2017 at Kuril Islands - they instantly contract and disappear in an unknown direction. However, we were able to collect two additional specimens in 2011 in Kamchatka waters and another specimen in Matua Island (middle group of Kuril Islands) and took 67 underwater photographs of 12 live specimens in both localities (Kamchatka and Kuril Islands). These photographs allowed not only to reveal the colouration of live specimens and to count their tentacles precisely but also were helpful in understanding the arrangement of the mesenteries and the tentacles. Thus, the species appear to be rare but its distinctive external appearance and morphology allowed us to describe it as a new species of the genus Paraedwardsia.

\section{Material and methods}

All available specimens were photographed underwater in their natural habitat to record colour, external appearance and position on substrate. Collected specimens were fixed in buffered (neutral) $4 \%$ solution of paraformaldehyde in seawater. The histological sections were prepared using isopropanol-mineral oil method (outlined in details by Sanamyan et al., 2019). Size ranges of cnidae were measured on small pieces of macerated tissue and the details of distribution of cnidae in different tissues were studied on histological sections stained by basic dyes (the method is described by Sanamyan et al., 2013). We should especially stress that we consider important to use the method of Hand (1954) to study cnidae. This method allows precise determination of the size ranges of cnidae (by scanning the whole sample for largest and smallest capsules) which we consider a more valuable characteristic for the species than mean values or size ranges obtained by the measurement of limited number of randomly selected cnidae. The latter method produces statistically significant differences not only between the samples from different specimens of the same species, but also between mean lengths of cnidae in replicate samples from the same specimen (see Williams, 1996). Cnidae terminology and the usage of other terms are the same as in our previous papers (see Sanamyan et al., 2012 for details). The relevant articles of the International Code of Zoological Nomenclature (ICZN, 1999) are referenced in the text as "Article ...". The specimens will be deposited in the Zoological Institute, St. Petersburg (ZIN). 
Table 1. Size ranges (length $\times$ width, in microns) and distribution of cnidae of Paraedwardsia malakhovi sp.n.

Таблица 1. Размеры (длина $\times$ ширина, в микронах) и распределение стрекательных капсул Paraedwardsia malakhovi sp.n.

\begin{tabular}{|l|l|c|c|}
\hline Body region & Cnidae & Size ranges $(\mu \mathrm{m})$ & $\mathrm{N}$ \\
\hline \multirow{2}{*}{ Scapus } & $(\mathrm{A})$ basitrichs (few) & $14-22 \times 2-3$ & $4 / 4$ \\
\cline { 2 - 4 } & $(\mathrm{B})$ basitrichs (common) & $40-62 \times 4-5$ & $4 / 4$ \\
\hline $\begin{array}{l}\text { Scapulus and } \\
\text { capitulum }\end{array}$ & $(\mathrm{C})$ basitrichs (common) & $16-24 \times 2-3.5$ & $2 / 2$ \\
\hline \multirow{2}{*}{ Tentacles } & $(\mathrm{D})$ spirocysts (very numerous) & $17-50 \times 2-5$ & $3 / 3$ \\
\cline { 2 - 4 } & $(\mathrm{E})$ basitrichs (common) & $32-46 \times 2.5-4$ & $3 / 3$ \\
\hline \multirow{2}{*}{ Actinopharynx } & $(\mathrm{F})$ basitrichs (common) & $23-31 \times 2-2.5$ & $2 / 2$ \\
\cline { 2 - 4 } & $(\mathrm{G})$ basitrichs (common) & $39-50 \times 3-4$ & $2 / 2$ \\
\hline \multirow{2}{*}{ Filaments } & $(\mathrm{H})$ basitrichs (numerous) & $39-58 \times 3.5-5$ & $4 / 4$ \\
\cline { 2 - 4 } & $(\mathrm{I})$ p-mastigophores A (very rare) & $11-28 \times 4.5-6$ & $3 / 4$ \\
\hline Endoderm & $(\mathrm{J})$ basitrichs (few) & $15-21 \times 2.5-4$ & $2 / 2$ \\
\hline
\end{tabular}

Letters in brackets correspond to letters in Fig. 5; "N" is the proportion of examined specimens that had a particular type of cnida.

\section{Taxonomy}

Order Actiniaria

Family Edwardsiidae Andres, 1881

Paraedwardsia Carlgren in Nordgaard, 1905

Paraedwardsia malakhovi sp.n.

Table 1; Figs. 1-5. 93.

Paraedwardsia sp.: Sanamyan, Sanamyan, 2020: 92

MATERIAL EXAMINED. Holotype (part of the specimen and histological sections): ZIN 12312, NW Pacific, East Kamchatka, Avacha Bay, Starichkov Island, $52^{\circ} 46.477^{\prime} \mathrm{N}, 158^{\circ} 36$. $726^{\prime} \mathrm{E}, 19 \mathrm{~m}, 1{ }^{\circ} \mathrm{C}$, collected by N. Sanamyan, 10 August 2010, one specimen. Paratypes: ZIN 12313, NW Pacific, East Kamchatka, Avacha Bay, Starichkov Island, $52^{\circ} 46.460^{\prime} \mathrm{N}, 158^{\circ} 36$. $723^{\prime} \mathrm{E}, 20 \mathrm{~m}, 2^{\circ} \mathrm{C}$, collected by N. Sanamyan, 2 June 2011, two specimens; ZIN 12314, NW Pacific, Kurile Islands, Matua Island, Point Kluv, $48^{\circ} 5.468^{\prime} \mathrm{N}, 153^{\circ} 15.679^{\prime} \mathrm{E}, 14 \mathrm{~m}, 3^{\circ} \mathrm{C}$, collected by N. Sanamyan, 19 August 2017, one specimen.

DESCRIPTION. The holotype was torn in two parts during the process of collecting, in preservative their entire length is $30 \mathrm{~mm}$ and diameter of the column is up to $6 \mathrm{~mm}$. The column is long, cylindrical, divided into the scapus, the scapulus and short capitulum (Fig. $2 \mathrm{~A}$ ). The proximal end of the column is tapering, the physa is not present. The scapus is 24 $\mathrm{mm}$ in length and $3.5 \mathrm{~mm}$ in diameter, covered by periderm. The scapulus is $2 \mathrm{~mm}$ long, wider than the scapus (6 $\mathrm{mm}$ in diameter), naked (not covered by periderm), has eight low scapular ridges. The capitulum is less than $1 \mathrm{~mm}$ in height, located just below the bases of the tentacles. The holotype has 32 tentacles, they all are visible on preserved specimen, the longest are about $3 \mathrm{~mm}$ in length and up to $0.9 \mathrm{~mm}$ in diameter. The tentacles are transversely wrinkled.

Among the paratypes one specimen (ZIN 12313) turned its inside out, its length (including the remained intact part of the scapus) is 25 $\mathrm{mm}$ and the diameter of the scapus is $6 \mathrm{~mm}$. Two other paratypes are represented by fragments of smaller size. On the underwater photographs of fully expanded live specimens the diameter of the crown of the tentacles is estimated as 3-4 $\mathrm{cm}$, the diameter of the disc appears to be less 
than $1 \mathrm{~cm}$ and the tentacles are up to $2 \mathrm{~cm}$ long. The column in the expanded state is probably less than 6-7 cm in length.

The number of the tentacles in different specimens varies from 24 to 36 . They are thin and tapering, all of about the same length.

Formalin preserved specimens are tan, the periderm is grayish. Live specimens are usually olive-brown-gray. Only the oral disc with the tentacles and the scapulus are visible on the surface (Fig. 1). Among the inner (endocoelic) tentacles four slightly larger are usually recognizable, they are located slightly closer to the mouth and correspond to the directive endocoels (at the corners of the mouth on the disc) and to the dorso-lateral primary endocoels (Fig. 1A, D). All the tentacles have whitish patches and strokes along the whole their length on the oral surface and the sides. The background colour of the inner (endocoelic) tentacles is darker in their basal parts. The oral disc may be darker or paler than the bases of the tentacles. In some specimens it may be whitish, often with dark radial lines corresponding to the insertions of the mesenteries (Fig. 1D). In other cases the disc is dark, deep-brown (Fig. 1B). Oral cone is not high and divided into eight segments by dark lines corresponding to the insertions of the macrocnemes. The actinopharynx is pale. The scapulus has a dark background with two wide transverse whitish bands divided by dark longitudinal lines marking the insertions of the macrocnemes (Fig. 1B, C). The insertions of the microcnemes are also marked by dark lines visible in most distal part of the column (in the capitulum) just below the tentacles (Fig. 1C). Some specimens from Kuril Islands are very brightly coloured, fluorescent rose or orange (Fig. 1A).

The periderm on the scapus is thin, covered by a firm mucous layer about $2 \mu \mathrm{m}$ in thickness with fine mud particles, small sand grains and epibionts. In particular, the whole periderm of the holotype is covered by a hydrorhiza (threads about $30-60 \mu \mathrm{m}$ in diameter attached to the periderm) of a hydrozoan with small whitish polyps (Fig. 3E).

The ectoderm of the scapus is $20-60 \mu \mathrm{m}$ in thickness. The periderm is attached to the ecto- derm or, occasionally in some parts detached from it. The mesogloea of the scapus is $30-80$ $\mu \mathrm{m}$ thick. Its outer (ectodermal) surface is not even but has numerous wrinkles and high «protuberances» (Fig. 2C), however we failed to find any well-formed tenaculi with modified ectoderm, although thin mesogloeal strands run through the ectoderm to the periderm. The mesogloea is much thicker in the scapular ridges, up to $400 \mu \mathrm{m}$ (Fig. 2D). In the capitulum it is of the same thickness as in the scapus, its ectodermal surface is smooth (Figs 2E, 3A). The endoderm is $50-100 \mu \mathrm{m}$ in thickness. The actinopharynx is short, reaches only the distal part of the scapus. It has eight longitudinal ridges with thickened mesogloea along the insertions of the macrocnemes. The actinopharynx has no recognizable siphonoglyphs, although in some sections the ventral fold of the actinopharynx, supported by ventral directives, is slightly deeper than other folds (Fig. 3A). The ectoderm of the actinopharynx is up to $90 \mu \mathrm{m}$ in thickness.

Eight macrocnemes run along the whole column. They are arranged as in all edwardsiids: there are two pairs of directives (dorsal and ventral) and two couples of dorso-lateral and ventro-lateral primary mesenteries with the retractors turned to the ventral pair of directives (Fig. 4). Microcnemes are present only in the most distal part of the column, in the region of the capitulum (Fig. 3A). They are represented by two couples of the microcnemes of the first cycle, paired with dorso-lateral and ventro-lateral macrocnemes, and by different number of secondary pairs of the microcnemes: up to three pairs in the dorsal exocoels, one pair in the lateral exocoels and up to two pairs in the ventral exocoels (Fig. 4). The microcnemes are very small, without retractors, filaments and gonads. The macrocnemes have strongly developed retractors, parietal muscles, gonads, trilobate and unilobate filament. Trilobate filaments are located in the distal parts of the mesenteries (just below the level of the actinopharynx), unilobate filaments present in the more proximal parts of the macrocnemes.

Retractor muscles are restricted, with rather long diffuse part located closer to the adaxial 

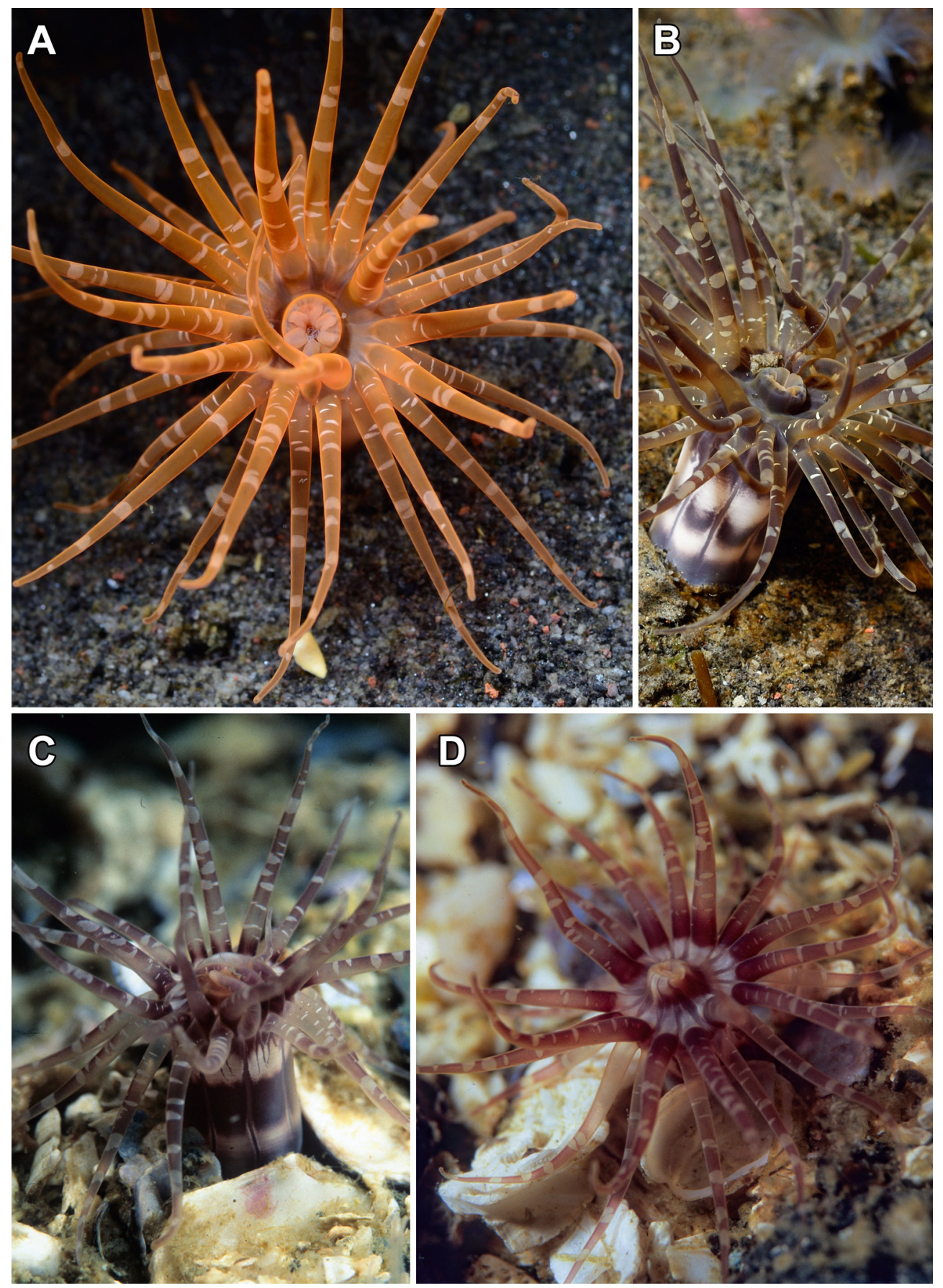

Fig. 1. Paraedwardsia malakhovi sp.n., underwater photographs of live specimens. A - a fluorescentorange specimen from Matua Island, ZIN 12314 (paratype); B - a specimen from Matua Island (not collected); C - ZIN 12312 (holotype); D - ZIN 12313 (paratype).

Рис. 1. Paraedwardsia malakhovi sp.n., подводные фотографии живых экземпляров. А 一 флуоресцентно-оранжевый экземпляр с о. Матуа, ZIN 12314 (паратип); В - экземпляр с о. Матуа (не собран); C - ZIN 12312 (голотип); D - ZIN 12313 (паратип). 

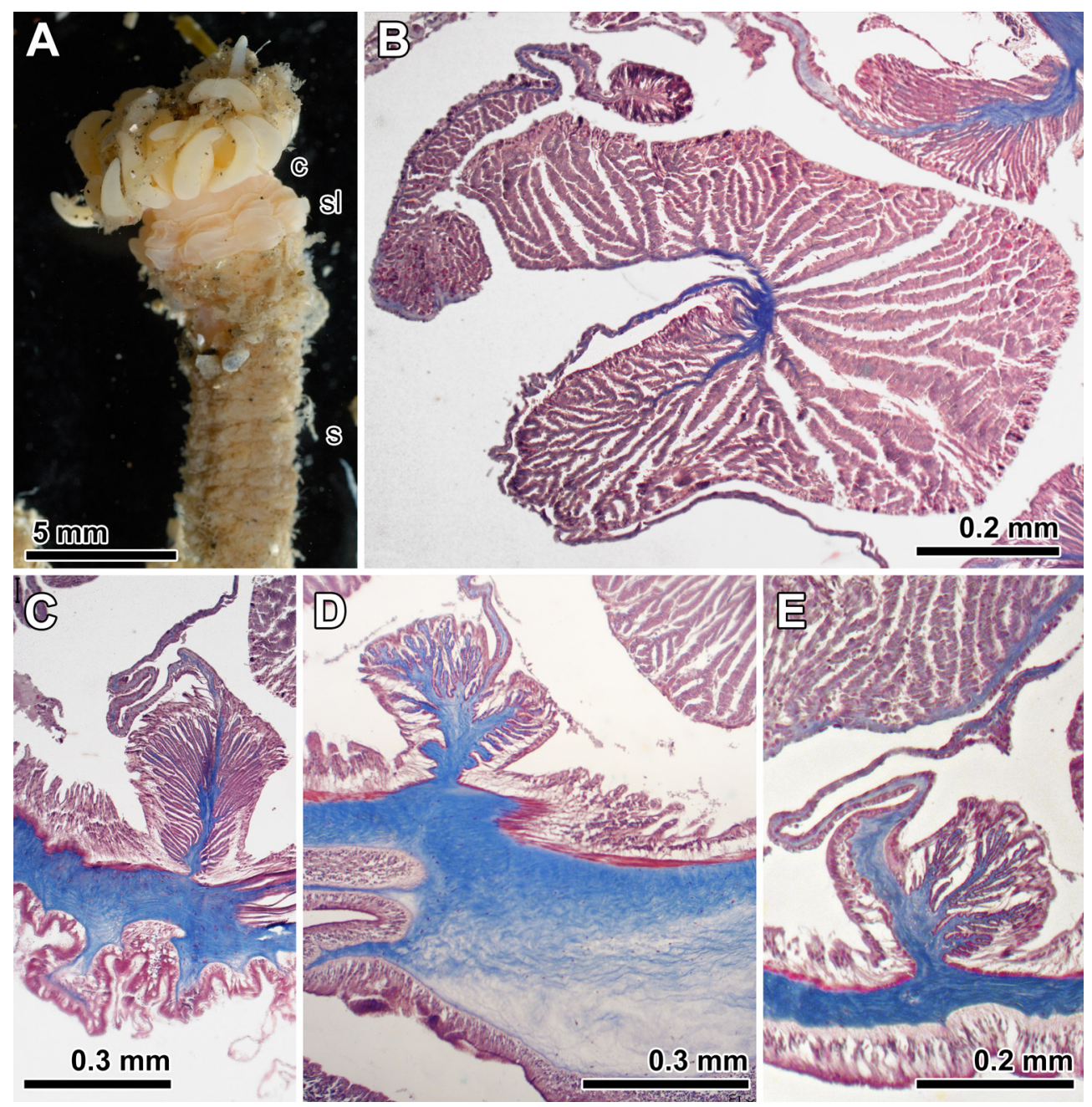

Fig. 2. Paraedwardsia malakhovi sp.n., holotype. A - preserved specimen; B - retractor muscle; C parietal muscle in the scapus; D - parietal muscle in the scapulus; E - parietal muscle in the capitulum. Abbreviations: c - capitulum; s - scapus; $\mathrm{sl}$ - scapulus.

Рис. 2. Paraedwardsia malakhovi sp.n., голотип. А — фиксированный экземпляр; В - ретрактор; С париетальная мускулатура в скапусе; D — париетальная мускулатура в скапулюсе; Е — париетальная мускулатура в капитулюме.

Сокращения: с - капитулюм; s - скапус; sl - скапулюс.

margin of the mesenteries and with large pennon about $500 \mu \mathrm{m}$ in length (on transverse section) on its abaxial side (=closer to the wall of the column) (Fig. 2B). In the distal part of the column the pennon becomes smaller and disappears in the distal part of the capitulum (Fig. $3 \mathrm{~A}$ ). Retractor muscles are composed of about 50 muscle processes, many of them are branched.
The parietal muscles have different appearance in the different regions of the body. In the middle part of the scapus the parietal muscles are developed symmetrically on both sides of each macrocneme. The parietal muscles extent to about $400 \mu \mathrm{m}$ along the macrocnemes. They are composed of about 20 muscle processes on each side, many of them, especially longer ones, 


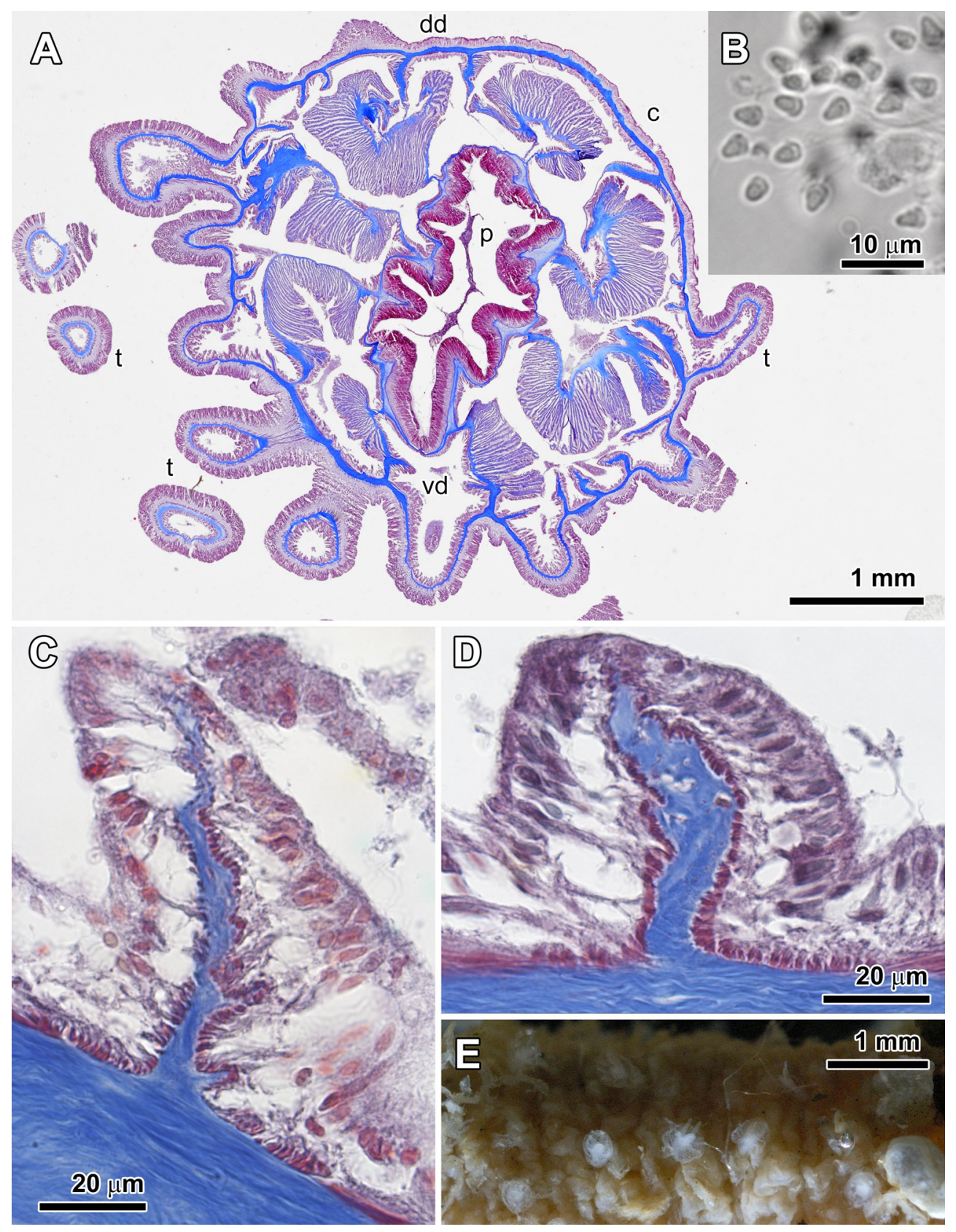

Fig. 3. Paraedwardsia malakhovi sp.n., holotype. A - transverse section of most distal part of the column (the level of capitulum); B - spermatozoa; C - microcneme of the first cycle; D - microcneme of the second cycle; E - small hydrozoan polyps attached to the scapus.

Abbreviations: $\mathrm{c}$ - capitulum; $\mathrm{dd}$ - dorsal directives; $\mathrm{p}$ - actinopharynx; $\mathrm{t}$ - tentacles; $\mathrm{vd}$ - ventral directives. Рис. 3. Paraedwardsia malakhovi sp.n., голотип. А - поперечный срез через капитулюм; В сперматозоиды; C — микромезентерий первого порядка; D — микромезентерий второго порядка; $\mathrm{E}$ мелкие гидроидные полипы на скапусе.

Сокращения: c - капитюлюм; $\mathrm{dd}$ - дорсальные направляющие пары мезентериев; $\mathrm{p}$ - глотка; $\mathrm{t}$ — щупальца; $\mathrm{vd}$ - вентральные направляющие пары мезентериев. 

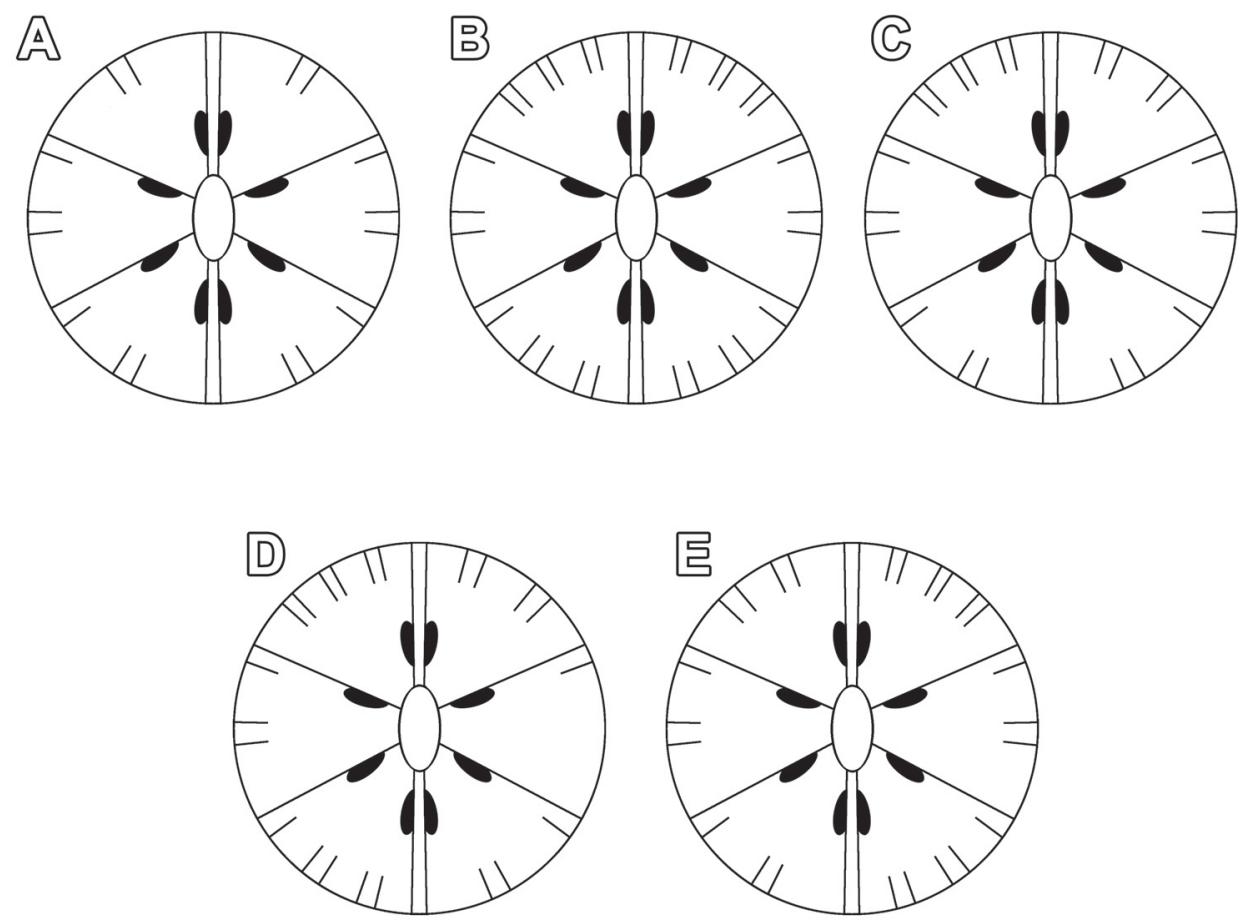

Fig. 4. Paraedwardsia malakhovi sp.n., arrangement of the mesenteries. A - a specimen with 24 tentacles; $\mathrm{B}$ - a specimen with 36 tentacles (paratype ZIN 12314); C — a specimen with 30 tentacles; D — a specimen with 30 tentacles (paratype ZIN 12313); E - a specimen with 32 tentacles (holotype ZIN 12312).

Рис. 4. Paraedwardsia malakhovi sp.n., расположение мезентериев A - экземпляр с 24 щупальцами; B - экземпляр с 36 щупальцами (паратип ZIN 12314); C - экземпляр с 30 щупальцами; D экземпляр с 30 щупальцами (паратип ZIN 12313); E - экземпляр с 32 щупальцами (голотип ZIN 12312).

are branched. The muscle processes composing the parietal muscles become gradually longer (to $200 \mu \mathrm{m}$ ) in the adaxial direction (=from the body wall to the axis of the column). In the adaxial end of the parietal muscle they become shorter so that the whole muscle has a triangular shape on the transverse section: narrow near the wall of the column and wide on the opposite end (Fig. 2C). Parietal muscles are expanded on the wall of the scapus on about $40-50 \mu \mathrm{m}$ on each side of the mesentery. In the distal part of the column parietal muscles become weaker, in the scapulus they are represented by two pennons (Fig. 2D) and in the capitulum only one pennon on the side of the retractor muscle remains while on the opposite side only short diffuse processes are present (Fig. 2E). The microcnemes some- times have few short muscle processes on the side facing to the endocoel (Fig. 3C). Longitudinal musculature of the microcnemes expands on the wall of the scapus in the same way as in macrocnemes (Fig. 3C, D). Longitudinal muscles of the tentacles and radial muscles of the oral disc are ectodermal.

The sexes are separate. The holotype is a male. Spermatozoa radially symmetric, triangular with rounded tip, 3.2-3.4 × 2-2.2 $\mu \mathrm{m}$ (Fig. 3B). Ova up to $200 \mu \mathrm{m}$ in diameter.

Cnidom includes spirocysts, basitrichs, $p$ mastigophores A (Tab. 1, Fig. 5). Most spirocysts in the tentacles have regularly coiled tubule as in gracile type, but many have irregularly coiled as in robust type with all transitional forms between them. Large basitrichs in the 


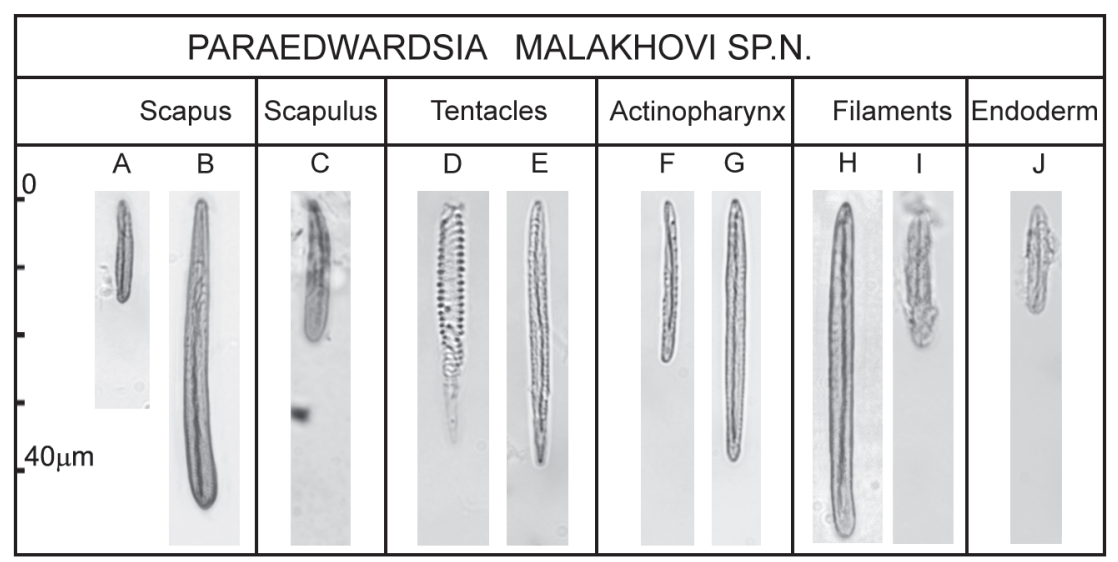

Fig. 5. Paraedwardsia malakhovi sp.n., distribution of cnidae (see Table 1 for size ranges).

Рис. 5. Paraedwardsia malakhovi sp.n., распределение книд (размеры указаны в табл. 1).

scapus appear to be arranged in groups, but nemathybomes not present. $P$-mastigophores A in the filaments are very rare, only six capsules were measured. Trilobate filaments have large basitrichs of the same type as in the unilobate filaments (Fig. 5H).

ETYMOLOGY. It is very pleasant for us to name this very beautiful species, which belongs to a genus named after famous zoologist MilneEdwards, in honor of our teacher, Vladimir V. Malakhov, a head of the Department of Invertebrate Zoology of the Faculty of Biology of the Lomonosov Moscow State University, an academician of the Russian Academy of Sciences, who always remembers his students, supports their work and whose 70th birthday is celebrated in this year. He taught us to understand the language of marine invertebrates, recognize them and their relationships and love them and their morphology more than their molecules.

HABITAT AND DISTRIBUTION. The species is known only from east (Pacific) coast of Kamchatka (Starichkov Island) and from Middle Kuril Islands (Matua Island). Known depth range is $14-22 \mathrm{~m}$. The species was recorded in the patches of sand or coarse gravel with broken shells located between large stones. It was not found on the extensive sandy or muddy areas. It occurs together with other burrowing Actiniaria, e.g. Charisea saxicola Torrey, 1902 and Halcampoides sp.
REMARKS. The generic assignment of the present species is not obvious. It lacks nemathybomes ("spheroid invaginations of the columnar ectoderm into the mesogloea laden with numerous nematocysts", Carlgren, 1949: 9) so the most species rich genera, Edwardsia Quatrefages, 1842 and Scolanthus Gosse, 1853 and also Edwardsianthus England, 1987, which have them, are excluded.

Among remaining genera two may potentially accommodate the present species, $E d$ wardsiella Andres, 1883 and Paraedwardsia Carlgren in Nordgaard, 1905. They both lack nemathybomes and have scapus covered by cuticle or periderm.

The first genus, to which the present species may be potentially assigned (especially if we concentrate only on the published diagnoses of edwardsiid genera and will not take in account the actual morphology of included species) is Edwardsiella Andres, 1883. This homogenous genus comprises four species closely resembling each other (see Sanamyan et al., 2018). They all are quite distinct from the present species. Unlike most other edwardsiids, the members of Edwardsiella usually occur on hard substrata, e.g. in narrow crevices of bedrock or in dead calyces of stony corals (e.g. Lophelia). They have characteristically looking scapulus which (unlike the scapulus of the present species) tapers distally and has eight prominent 
ridges, a feature that alone allows to recognize Edwardsiella species on the underwater photographs in many cases. This difference is well illustrated by Stephenson (1928, Plate 1). According to Carlgren (1892) the type species of Edwardsiella, Edwardsia carnea Gosse, 1856, has a hexamerous arrangement of the tentacles $(6+6+12+$ incomplete fourth cycle). Carlgren $(1892,1921)$ considered this feature as important distinguishing feature for the genus $\mathrm{Mil}$ needwardsia Carlgren, 1892 (a junior subjective synonym of Edwardsiella). The arrangement of the tentacles in the present species is not hexamerous and taking in account other differences discussed above it hardly can be assigned to Edwardsiella.

The second potentially appropriate genus is Paraedwardsia. Originally, Carlgren (see Nordgaard, 1905: 158) distinguished Paraedwardsia from Edwardsia only on the basis of the presence of tenaculi in Paraedwardsia: "Paraedwardsia is characterized by 8 complete mesenteries like Edwardsia, but the scapus in Paraedwardsia is furnished with papilla like Halcam$p a$, and foreign bodies (grains of sand) are fastened to these papillae". Carlgren (1921) provided much more detailed description of Paraedwardsia and two species he included in it, $P$. arenaria Carlgren in Nordgaard, 1905 (the type species of the genus) and $P$. sarsii (Dueben et Koren, 1847). The first species, $P$. arenaria, has well-formed tenaculi to which sand grains are attached. The second species, $P$. sarsii, has much more scattered tenaculi: they were completely overlooked by Appellöf (1892), who identified the specimens as Edwardsia carnea and said that the scapus is quite smooth, but Carlgren (1921: 73) stated that "the scapus is in fact provided by Halcampa-papillae to which small sand grains are sometimes attached in the proximal part of the scapus". Later, Carlgren (1951, 1956) described two abyssal species, $P$. abyssorum Carlgren, 1951 and $P$. lemchei Carlgren, 1956, in which he failed to find any tenaculi but also assigned them to Paraedwardsia assuming that numerous mesogloeal papillae he saw on the scapus indicate that the tenaculi may have been present. Sanamyan \& San- amyan (2018) described an abyssal Paraedwardsia species ( $P$. hadalis Sanamyan et Sanamyan, 2018) with indiscernible (or very poorly discernible) tenaculi undoubtedly related to two Carlgren's abyssal Paraedwardsia spp. In contrast, another abyssal species of Paraedwardsia, P. heia Daly et Ljubenkov, 2008, has strongly developed tenaculi and densely covered by sand (see Daly, Ljubenkov, 2008, Fig. 9). Thus, currently the genus Paraedwardsia comprises species with strongly developed tenaculi and species in which the tenaculi poorly discernible (or, possibly, absent altogether). Whether they are correctly united in one genus is an open question. In the present paper we prefer not to revise the genus and to include the present species to Paraedwardsia.

Comparison with other species of the genus. The genus Paraedwardsia currently contains seven species (overviewed in Sanamyan, Sanamyan, 2018). Four of them are abyssal and obviously distinct from P. malakhovi sp.n. Three remaining species include two European species (from Norway), P. arenaria and P. sarsii, and one nominal species described from Japan, P. cretata (Stimpson, 1856). Paraedwardsia arenaria has strongly developed tenaculi with attached sand grains and only 16 tentacles (much fever than in P. malakhovi sp.n.) Paraedwardsia sarsii has up to 28 tentacles (or, occasionally, possibly more) but the retractors are very weak, especially in comparison with the present species, with only 15-20 short muscle processes (Carlgren, 1921). The remaining species was described as Edwardsia cretata by Stimpson (1856). The original description consists of four lines of text only but states that the body is covered by sand (a feature that excludes the identity with the present species). According to Fautin (2016) the type specimens were not found. Verrill (1868), who saw original Stimpson's (1856) specimen, suggested that it may belong to Phellia. Uchida \& Soyama (2001) published a photograph of a species they identified as Epiphellia aff. cretata which differs considerably from the present species. It may be concluded that the generic and familiar affinity of Edwardsia cretata described Stimpson (1856) 
is obscured and cannot be revealed from available information. It assignment to Paraedwardsia not justified and we prefer to treat it as a nomen dubium.

\section{Nomenclatural notes}

Paraedwardsia Carlgren in Nordgaard, 1905. The genus was established in a work of Nordgaard (1905: 158) as "Paraedwardsia arenarea, Carlgr. nov. gen. nov. sp." with a reference to a written communication received from Carlgren. According to Article 50.1 the authorship of both names (generic and specific) belongs to Carlgren. Subsequent authors spelled the species name as "arenaria". Fautin (2016) correctly noted that this spelling must be retained as being in prevailing usage according to Article 33.3.1.

Edwardsiella Andres, 1883. Originally Andres (1883) separated this genus from Edwardsia solely on the basis of the number of the tentacles. He created Edwardsiella to include four Edwardsia species which have more than 16 tentacles. The type species is Edwardsia carnea Gosse, 1856, designated subsequently by Manuel (1981). Carlgren (1892) wrote that the number of the tentacles by itself is not a valid feature to separate these genera but pointed on the differences in the arrangement of the tentacles, a feature treated by him as much more important than a number of the tentacles. Basing solely on this feature he created a genus Milneedwardsia.

Milneedwardsia Carlgren, 1892. Originally this genus was created for two species: Edwardsia carnea Gosse, 1856 and Milneedwardsia loveni Carlgren, 1892. Daly (2002b) stated that M. loveni Carlgren, 1892 is a nomen nudum and therefore E. carnea is the type species of Milneedwardsia by monotypy. Fautin (2016: 295) also stated that Milneedwardsia loveni Carlgren, 1892 is a nomen nudum and, therefore, unavailable according to Article 12.1 (but become available from Carlgren, 1893). Nevertheless, in the same paper she stated that $M$. loveni Carlgren, 1892 is the type species of Milneedwardsia. Actually the work of Carlgren
(1892) contains enough information on the morphology of this taxon, it cannot be considered a nomen nudum and is an available name. As a sequence, the type species of Milneedwardsia cannot be fixed by monotypy. Type species of Milneedwardsia was fixed subsequently by Carlgren (1949) who indicated " $F$. (Milne-Edwardsia) loveni Carlgren 1892" as a type species for Fagesia Delphy, 1938. Since Fagesia Delphy, 1938 is a replacement name for Milneedwardsia Carlgren, 1892, they have the same type species and "type fixation for either applies also to the other, despite any statement to the contrary" (Article 67.8). Milneedwardsia Carlgren, 1892 is a junior homonym of Milneedwardsia Bourguignat, 1877 (Mollusca) and therefore is invalid.

Fagesia Delphy, 1938. This name was suggested by Delphy (1938) as a replacement name for Milneedwardsia Carlgren, 1892. Fagesia Delphy, 1938 is a junior homonym of Fagesia Pervinquière, 1907 (Mollusca) and, as Milneedwardsia Carlgren, 1892, is invalid. Both, Fagesia Delphy, 1938 and Milneedwardsia Carlgren, 1892, are junior subjective (because they have different type species) synonyms of $E d$ wardsiella and therefore the replacement name not required.

Milneedwardsiidae Carlgren, 1892. Carlgren (1892) created this family to include only one genus, Milneedwardsia Carlgren, 1892. Originally he considered the hexamerous arrangement of the tentacles as the only feature separating the genus Milneedwardsia from Edwardsia and the family Milneedwardsiidae from Edwardsiidae. Later, Carlgren (1921) recognized it as a subfamily within Edwardsiidae and added (with some hesitation as it seems from his text) the second genus, Paraedwardsia to Milneedwardsiinae. Carlgren (1921: 59) stated that the tentacles in Milneedwardsiinae are "commonly hexamerously arranged" but the main feature distinguishing it from Edwardsiinae is the absence of nemathybomes. Daly (2002a) recognized Milneedwardsiinae with four included genera (Drillactis Verrill, 1922, Edwardsiella, Nematostella Stephenson, 1935 and Paraedwardsia). However, Milneedwardsiidae is in- 
valid due to homonymy of the name of the type genus (Article 39). According to Article 39 if "[invalid due to homonymy of the type genus] family-group name is in use it must be replaced either by the next oldest available name from among its synonyms [...], or, if there is no such synonym, by a new name based on the valid name (whether a synonym or a new replacement name (nomen novum)) of the former type genus." There are no available synonyms of Milneedwardsiinae and in accordance with the Article 39 we propose a new family-group name based on the valid name of its type genus, Edwardsiella: subfamily Edwardsiellinae nom.n. for Milneedwardsiinae Carlgren, 1892. Type genus of Edwardsiellinae nom.n. is $E d$ wardsiella Andres, 1883 (Article 16.2). See also Article 13.1.3. Whether Paraedwardsia, which currently comprises several species with different morphologies, or other edwardsiid genera lacking nemathybomes, should be grouped together with Edwardsiella within Edwardsiellinae nom.n. is still an open question that requires further investigation.

Acknowledgments. The authors express their sincere gratitude to the team of "Podvodremservice" for providing access to the work in the sea and diving operations and for loaning equipment for diving on the Kuril Islands; to Elena Panina, a colleague who helped the authors in their field work; to participants of the 20-th and 21-th Kamchatka-Kuril expeditions in 2016 and 2017 of the "Russian Geographical Society" to the Matua Island (middle Kuril Islands) and especially to the leaders of the expeditions Yevgeny Vereshchaga and Irina Viter, without whose enthusiasm the work on the island would not been possible, to Yevgeny Drashchev, Vladimir Anisimov, Roman Imangulov, Peter Rudev, Boris Koval, Lyubomir Medvedenko for support and assistance in the field work; to the Expeditionary Center of the Ministry of Defense of the Russian Federation, represented by Evgeny Binyukov and personally to Alexander Ageev for support in difficult circumstances and assistance in field work and to Captain of the First Rank Vyacheslav N.
Trusov for a warm welcome and comfortable working conditions on Matua Island; All-Russian non-governmental organization "Russian Geographical Society" for their grants supporting our work on Matua Island in 2017 and publication of a two-volume atlas on fauna and flora of this island, where a part of the material used in the present work was collected. Finally, we must say that all our scientific work would have been impossible without the support of Dr. Alexey Tokranov, the former (unfortunately) director of Kamchatka Branch of Pacific Geographical Institute FEB RAS who during his directorship was able to create very good conditions for us that allowed us to concentrate on our scientific work without any restrictions in selecting the subject for our studies or other limitations and unnecessary duties.

\section{References}

Andres A. 1883. Le Attinie // Atti dell' Accademia de Lincei. Vol.14. P.211-673.

Appellöf A. 1892. Zur Kenntniss der Edwardsien // Bergens Museums Aarsberetning. 1891. Nr.4. S.3-31.

Carlgren O. 1892. Beiträge zur Kenntnis der Edwardsien // Öfversigt af Kongliga Vetenskaps-Akademiens Förhandlingar. S.451-461.

Carlgren O. 1893. Studien über nordische Actinien // Kungliga Svenska Vetenskapsakademiens Handlingar. Bd.25. S.1-148. doi: 10.5962/bhl.title.11612

Carlgren O. 1921. Actiniaria Part $1 / /$ The Danish Ingolf Expedition. Vol.5. No.9. Pt.1. P.1-241.

Carlgren O. 1949. A survey of the Ptychodactiaria, Corallimorpharia and Actiniaria // Kungliga Svenska Vetenskapsakadamiens Handlingar. Vol.1. P.1-121.

Carlgren O. 1951. Actiniaria // Reports of the Swedish deep-sea expedition. Vol.2. Zoology. No.8. P.101104.

Carlgren O. 1956. Actiniaria from depths exceeding 6000 meters // Galathea report. Vol.2. Scientific results of the Danish deep-sea expedition round the World 195052. P.9-16.

Daly M. 2002a. A systematic revision of Edwardsiidae (Cnidaria, Anthozoa)// Invertebrate Biology. Vol.121. P.212-225.

Daly M. 2002b. Taxonomy, anatomy, and histology of the lined sea anemone, Edwardsiella lineata // Proceedings of the Biological Society of Washington. Vol.115. P.868-877.

Daly M., Ljubenkov J.C. 2008. Edwardsiid sea anemones of California (Cnidaria: Actiniaria: Edwardsiidae), with descriptions of eight new species // Zootaxa. Vol.1860. P.1-27. doi: 10.11646/zootaxa.1860.1.1 
Fautin D.G. 2016. Catalog to families, genera, and species of orders Actiniaria and Corallimorpharia (Cnidaria: Anthozoa) // Zootaxa. Vol.4145. No.1. P.1-449. doi: 10.11646/zootaxa.4145.1.1

Hand C.H. 1954. The sea anemones of central California Part I. The corallimorpharian and athenarian anemones // Wasmann Journal of Biology. Vol.12. P.345375.

ICZN [International Commission on Zoological Nomenclature]. 1999. International code of zoological nomenclature. Fourth edition // London: International trust for zoological nomenclature. 306 p. doi: 10.5962/ bhl.title.50608

Izumi T., Fujita T. 2018. Description of three new species of Scolanthus (Cnidaria, Anthozoa, Actiniaria, Edwardsiidae): first records of the genus from Japan // ZooKeys. Vol.794. P.1-21. doi: 10.3897/zookeys. 794.25243

Izumi T., Ise Y., Yanagi K., Shibata D., Ueshima R. 2018a. First detailed record of symbiosis between a sea anemone and homoscleromorph sponge, with a description of Tempuractis rinkai gen. et sp. nov. (Cnidaria: Anthozoa: Actiniaria: Edwardsiidae) // Zoological Science. Vol.35. P.188-198. doi: 10.2108/zs170042

Izumi T., Yanagi K., Fujita T. 2018b. Re-description of Metedwardsia akkeshi (Cnidaria: Anthozoa: Actiniaria: Edwardsiidae), discovered in Akkeshi, Hokkaido, almost 80 years after original description, with a revision of the diagnosis of genus Metedwardsia // Species Diversity. Vol.23. P.135-142. doi: 10.12782/ specdiv.23.135

Izumi T., Fujita T. 2019. Two species of Edwardsia having gigantic nematocysts, $E$. aff. tuberculata and E. alternobomen sp. nov. (Cnidaria; Anthozoa; Actiniaria; Edwardsiidae) from Japan // Zootaxa. Vol.4661. No.3. P.533-544. doi: 10.11646/zootaxa.4661.3.7

Kostina E. 2008. [Species diversity and distribution of sea anemones (Athenaria) on the shelf of East Sakhalin] // Sovremennoye sostoyaniye vodnykh bioresursov. Vladivostok: TINRO-center. P.130-132 [in Russian].

Manuel R.L. 1981. British Anthozoa keys and notes for the identification of the species. London, New York, Toronto, Sydney, San Fransisco: Academic Press. $241 \mathrm{p}$.

Nordgaard O. 1905. Hydrographical and Biological Investigations in Norwegian Fiords. Bergen: John Grieg. $254 \mathrm{p}$.

Sanamyan N.P., Sanamyan K.E. 2018. Paraedwardsia hadalis, a new ultra-abyssal sea anemone (Actiniaria: Edwardsiidae) from Aleutian Trench // Invertebrate Zoology. Vol.15. No.1. P.42-50. doi: 10.15298/invertzool.15.1.03

Sanamyan N.P., Sanamyan K.E., McDaniel N., Bocharova E.S. 2018. First record of two genera of sea anem- ones (Cnidaria: Actiniaria), Octineon and Edwardsiella, from the North Pacific Ocean // Invertebrate Zoology. Vol.15. No.1. P.1-18. doi: 10.15298/invertzool.15.1.01

Sanamyan N.P., Sanamyan K.E., McDaniel N., Martynov A.V., Korshunova T.A. Bocharova E.S., 2019. A revision of sea anemones of the genus Cribrinopsis Carlgren, 1921 (Actiniaria: Actiniidae) from British Columbia with the description of a new species // Marine Biodiversity. Vol.49. No.4. P.1951-1969. doi: 10.1007/s12526-019-00956-w

Sanamyan N.P., Sanamyan K.E., Tabachnick K. 2012. The first species of Actiniaria, Spongiactis japonica gen.n., sp.n. (Cnidaria: Anthozoa) an obligate symbiont of a glass sponge // Invertebrate Zoology. Vol.9. No.2. P.127-141. doi: 10.15298/invertzool.09.2.05

Sanamyan N.P., Sanamyan K.E. 2012. Edwardsia sojabio sp. n. (Cnidaria: Anthozoa: Actiniaria: Edwardsiidae), a new abyssal sea anemone from the Sea of Japan // Deep-Sea Research II. Vol.86-87. P.225230. doi: 10.1016/j.dsr2.2012.08.013

Sanamyan N.P., Sanamyan K.E. 2020. [Sea anemones (Anthozoa of the order Actiniaria)] // K.E. Sanamyan, N.P. Sanamyan (eds.). Flora i Fauna ostrova Matua (srednie Kuril'skie ostrova): polevoi opredelitel. Vol.1. Sea. Cherepovets: Intron. P.58-97 [in Russian].

Sanamyan N.P., Sanamyan K.E., McDaniel N. 2013. Two new shallow water sea anemones of the family Actiniidae (Cnidaria: Anthozoa: Actiniaria) from British Columbia (NE Pacific) // Invertebrate Zoology. Vol.10. No.2. P.199-216. doi: 10.15298/invertzool.10.2.01

Stephenson T.A. 1928. The British Sea Anemones. Volume I. London: The Ray Society. 148 p.

Stimpson W. 1856. Descriptions of some of the new marine invertebrata from the Chinese and Japanese seas // Proceedings of the Academy of Natural Sciences of Philadelphia. Vol.7. P.375-384.

Uchida H., Soyama I. 2001. Sea anemones in Japanese waters. Tokyo: TBS Britannica. 157 p.

Verrill A.E. 1868. Synopsis of the polyps and corals of the North Pacific Exploring Expedition, under Commodore C. Ringgold and Capt. John Rodgers, U.S.N., from 1853 to 1856 . Collected by Dr. Wm. Stimpson, Naturalist to the Expedition. Part IV. Actiniaria // Communications of the Essex Institute. Vol.5. P.315330 .

Williams R.B. 1996. Measurement of cnidae from sea anemones (Cnidaria: Actiniaria): statistical parameters and taxonomic relevance // Scientia Marina. Vol.60. No.2-3. P.339-351.

Responsible editor V.N. Ivanenko 